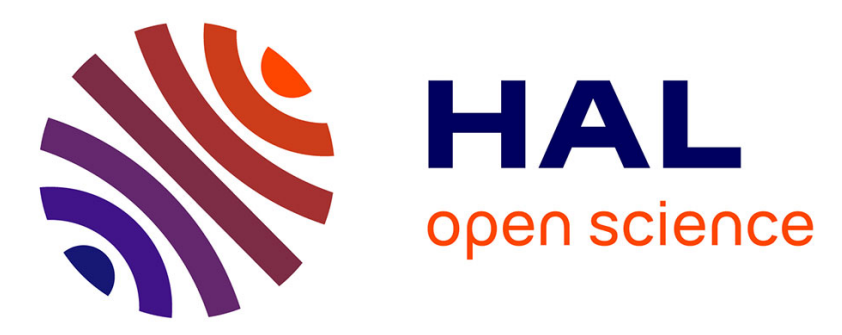

\title{
Water as a critical zone currency: linking water storage and age to root uptake and biogeochemical transport
}

Sylvain Kuppel, Isabelle Braud, Yves Godderis, Sekhar Muddu, Jean Riotte, Laurent Ruiz

\section{- To cite this version:}

Sylvain Kuppel, Isabelle Braud, Yves Godderis, Sekhar Muddu, Jean Riotte, et al.. Water as a critical zone currency: linking water storage and age to root uptake and biogeochemical transport. EGU General Assembly 2020, May 2020, Vienna, Austria. 10.5194/egusphere-egu2020-15958 . hal03126261

\section{HAL Id: hal-03126261 \\ https://hal.science/hal-03126261}

Submitted on 30 Jan 2021

HAL is a multi-disciplinary open access archive for the deposit and dissemination of scientific research documents, whether they are published or not. The documents may come from teaching and research institutions in France or abroad, or from public or private research centers.
L'archive ouverte pluridisciplinaire HAL, est destinée au dépôt et à la diffusion de documents scientifiques de niveau recherche, publiés ou non, émanant des établissements d'enseignement et de recherche français ou étrangers, des laboratoires publics ou privés.

\section{(c)(1)}

Distributed under a Creative Commons Attribution| 4.0 International License 

to root uptake and biogeochemical transport

Sylvain Kuppel 1,2, Isabelle Braud 1, Yves Goddéris 3 , Sekhar Muddu 4,5, Jean Riotte 3,5 , and Laurent Ruiz 5,6

sylvain.kuppel@inraeff

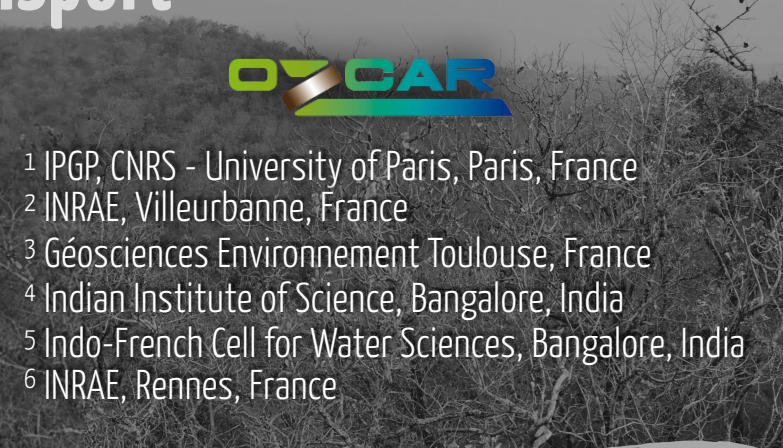

\section{Background}

Analyzing responses of water ages to changes in hydrological status (e.g., storage) gives insights into water-mediated $\mathrm{CZ}$ functions.

Prospect. Anticipating sensitivity of ecosystem health and biogeochemical balance to changing climatic and land-water use conditions.

\section{Questions}

How do water flow paths control 1. the age of root uptake

2. the variability of water chemistry within and across the critical zone?

\section{Method}

Coupling spatially-distributed ecohydrological and geochemical modeling approaches in data-rich critical zone observatories

\section{Study site}

Mule Hole, a $4 \mathrm{~km}^{2}$ sub-humid intermittent catchment in SW India, with a deep weathered profile on a granitogneissic basement, covered by a dry deciduous forest
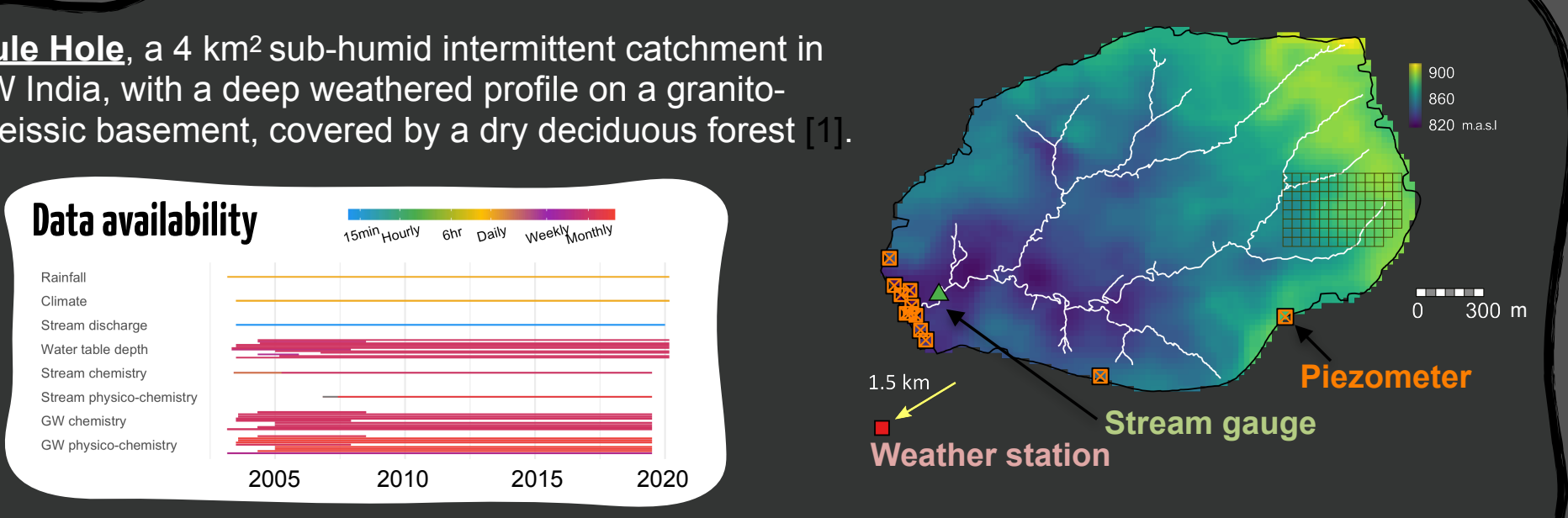

Tracking water in the critical zone

Ech $\mathrm{H}_{2} \mathrm{O}$-iso, a process-based and spatially-distributed ecohydrological model, tracking water signature (age and conservative tracers) across grid cells and CZ compartments [2].

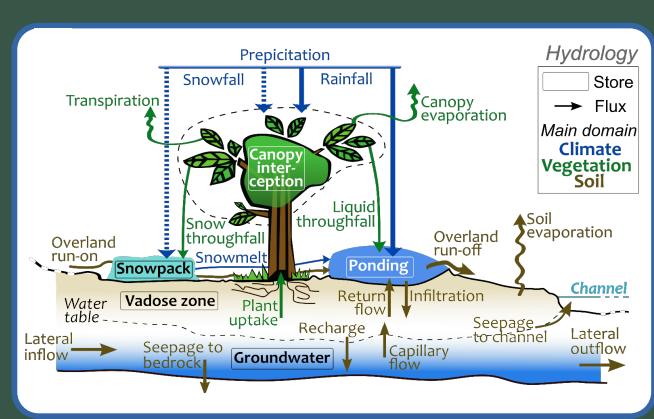

Preliminary configuration Daily simulations at $90 \mathrm{~m}$ resolution. 2005-2017 (+90-year spinup) $35 \mathrm{~m}$-deep hydrological domain.
Uniform vegetation cover (deeply-rooted trees $90 \%)$. Manual parameters calibration to discharge and piezometric levels.

Root uptake accesses deep, old waters, consistent with previous studies [3]. Hysteretic relationship with CZ storage reflect cross-season carry-over. Large inter annual variability from hydroclimate.

Biogeochemical budget WITCH, a modular chemical weathering model - simulating dissolution/precipitation rates of mineral phases based on kinetics laws [4] (spatialized version).

Preliminary simulations

Monthly simulations forced with $\mathrm{EcH}_{2} \mathrm{O}$-iso water fluxes and contents. No spinup. Laterally-uniform mineralogy, 9 vertical layers.

Example with $\mathrm{Ca}^{2+}:$ strong signature of varying water fluxes and storage
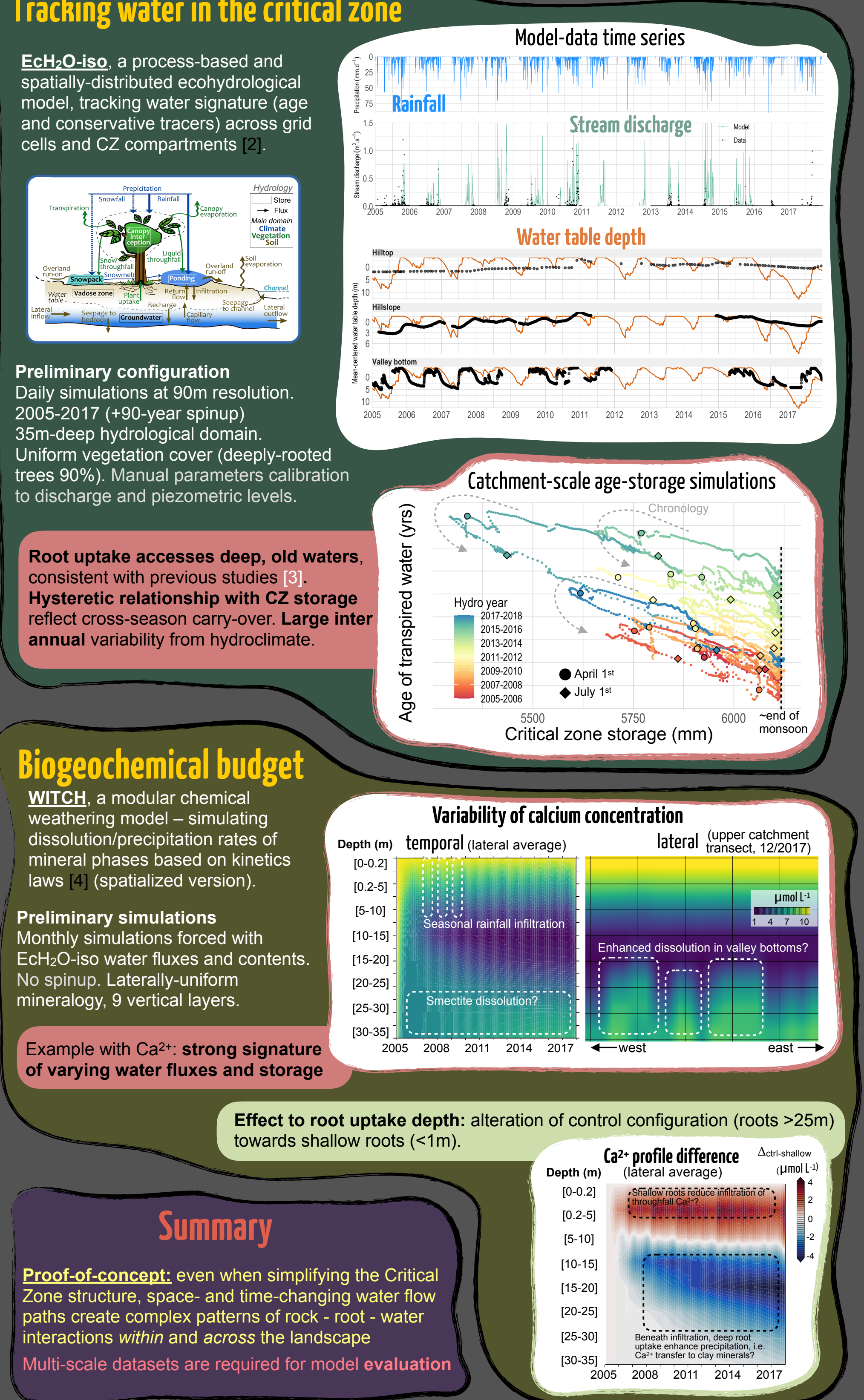

[1] Riotte et al. (2014), Geochimica et Cosmochimica Acta, 145, 116-138 [link]. [2] Kuppel et al. (2018), Geosci.
References Model Dev. 11(7), 3045-3069 [link]. [3] Chitra-Tarak et (2018), Journal of Ecology, 106(4), 1495-1507 [link]

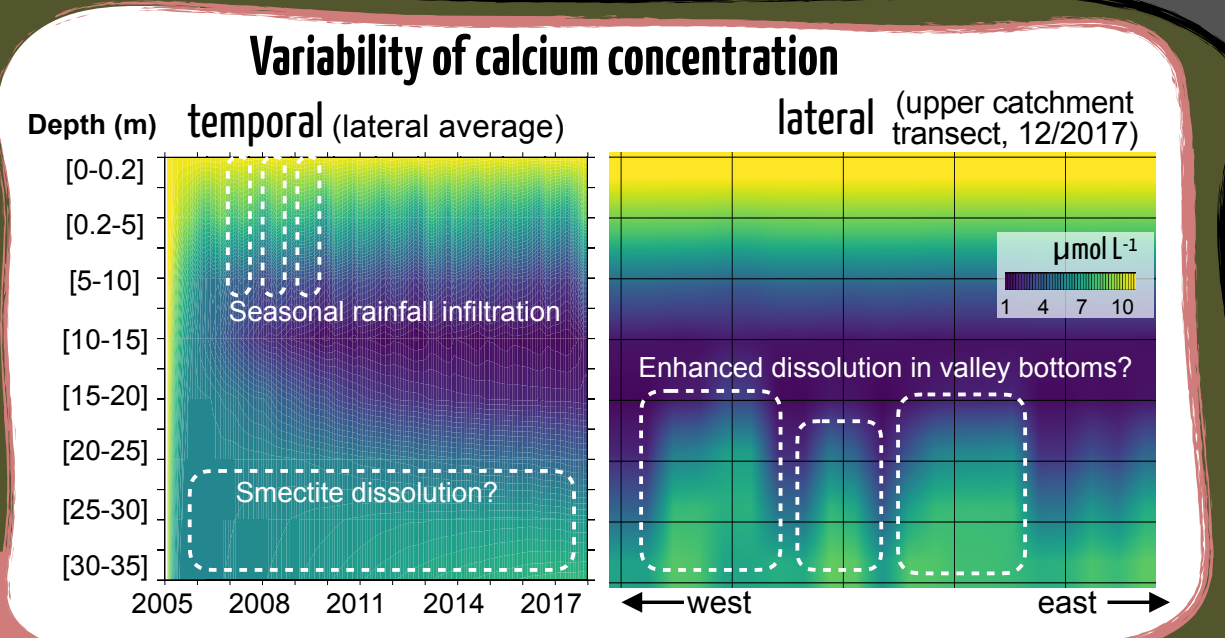

4] Goddéris et al. (2006), Geoch lica et Cosmochinca Acta, 70(5), 1128-1147 [link]. 